\title{
Fun Learning History: Explore the History of Water Sites Based on Android
}

\author{
https://doi.org/10.3991/ijet.v16i07.21215
}

\author{
Wahyu Djoko Sulistyo ( $\left.{ }^{\varpi}\right)$, Moch. Nurfahrul Lukmanul Khakim, \\ Najib Jauhari, Rena Dwita Anggraeni \\ Universitas Negeri Malang, Malang, Indonesia \\ Wahyu.djoko.fis@um.ac.id
}

\begin{abstract}
Technological progress is a challenge for learning history in the present era. The development of student learning patterns is in accordance with the times. The latest learning models are designed according to needs. In learning history, the use of local historical sources is of concern and importance. Apart from this, the study of local history is a source of character values. The attractive packaging of the local history learning design is the focus of this research. Namely by packaging local history in a fun learning design in an Android application package. Local historical sites that are utilized are Dampul spring which is located in Besta Village, Tulungrejo Village, Bumiaji District, Batu City. The use of Dampul springs varies from melasti for Hindus to consumption by residents of Besta \& Village and Tulungrejo Villages. Social and cultural values and history are the potential of this water site so that it can be used as a source of learning. The method in this research includes qualitative and qualitative methods with direct field reviews, simulations and filling out questionnaires. In this activity, observations and interviews were carried out with managers and the supporting community. Historical methods are also used to reveal the historical narrative of this site. Furthermore, the syntax of learning game learning based on android is compiled by utilizing this site. Field data from this learning simulation generally includes 4 criteria, namely application view, content of the material, fun learning and learning objectives achieved, showing $77 \%$ achievement. This achievement shows that the learning design is effective.
\end{abstract}

Keywords - Spring water, fun learning history, android

\section{$1 \quad$ Introduction}

History learning enters an era of unavoidable technological advances. This is a challenge for educators to synergize technology in education to support the implementation of learning [1], [2]. The learning patterns of students today have changed a lot, they prefer learning that is fun than procedural ones. The existence of androids has also become part of their daily lives [3]. Android has become a device in a learning scheme for both teachers and students today. Its use as a learning resource or a supporting device for the implementation of learning designs [4]-[6]. Lately, there have been various studies on the effectiveness of android as a learning device favored by students, and the 
results show optimal results[4], [7], [8]. This becomes natural because their mindset is in tune with the progress of the times. Therefore, in history learning, the study of the past is packaged in a modern way through an Android application, this is certainly interesting for students so that learning becomes fun and learning objectives will be achieved.

In historical learning, local studies are a potential that is owned by the region and can be used as a source of knowledge and learning for the community [9]. This is necessary because to raise awareness of local history is very important for the community and students. Because the community and students must be proud of the potential of the region which is still related to the present. This pride should not be used as a tool to divide Indonesia. Because one of what makes Indonesia diverse in terms of ethnicity, race and culture is local history itself. That way local history makes Indonesia rich in ethnic, racial, religious and cultural diversity in each region so that Indonesians can respect each other's diversity [10], [11]. The diversity of local history in each region must have its own uniqueness and characteristics. The uniqueness and characteristics of the local history will return to local communities who protect and preserve [12], [13]. Through the caretaker, cultural officials, and cultural officers can help introduce or explain how the local history is. Local history which is limited in resources needs to be redeveloped in accordance with the socio-cultural background in which the school is located [14]. Due to limited resources, material about local history is rarely brought up in lessons. Even though there are many lessons that can be taken from local history such as local wisdom that is owned, why the community, especially students, must be aware of local history, and why this local history must be preserved[15], [16].

In line with previous research, studies of the local history of springs have been widely discussed by researchers. For example, a study that discusses aspects of local village history that are still related to water sources, forms of local wisdom of local communities in managing water sources, aspects of local village culture that play an important role in environmental conservation [17]. The form of local wisdom of the community in maintaining the availability of sources, such as site rituals, ceremonies, various local suggestions and prohibitions, as well as several myths that develop in the community. The study is to identify how the community cares about local history and local wisdom contained in the local village, especially there are springs, then the attitude of the community in managing and utilizing water sources so that they are maintained and consumed by the local community, the habits of local residents who maintain their will history and local wisdom that always provides an example for children who are still in school. Because then students will not forget that they have a local history of their area that needs to be developed [18]-[20].

The Kota Batu area is the upstream part of the Brantas River Basin. The city of Batu has hundreds of water sources that have strategic value for meeting the clean water needs of Batu City, Malang City and Malang Regency. Batu City, which is surrounded by several mountains with relatively low temperatures, is very suitable for planting various crops as well as plantations [21]. To fertilize plants and plantations, it will not be separated from running water. This water is obtained from various ways, such as making a small pond as a water reservoir or obtaining it directly from a nearby source. The city of Batu, which is rich in springs, makes the community take part in protecting 
and preserving the existing resources in each region. The people of Batu City will not give permission to anyone who will take over the spring to be used as a construction project location. Because of their daily need for water, most of the agricultural and plantation needs of Batu City residents come from springs[22], [23].

The explanation above explains the benefits and importance of local history to serve as teaching material for students. The use of local history as teaching material is a positive value in the morning for students in shaping their character [24]-[26]. The attractive packaging of the local history teaching materials will determine success in learning. Students will be more interested if the packaging matches their habitual patterns. Therefore, Android is an effective solution for packaging the material in this study. Several previous studies conducted by researchers with a similar topic, namely the use of android to package local history material have proven effective [27], [28]. Therefore, this article discusses the existence of the Dampul water site in the city of Batu, its history and its use, a fun learning design simulation based on Android and the achievement of its learners.

\section{Method}

This study used a qualitative approach which was carried out without statistical procedures, but by collecting information and data that had been carefully interpreted and then interpreted. The data collection was carried out by careful observation, including descriptions in a detailed context such as notes from in-depth interviews. [29]. Observations were made directly at the Dampul water site which is administratively located in the town of Batu. The data collection technique is in the form of interviews with several informants / informants who are able to provide a little description of information or have data related to research conducted by researchers. The interview is one of the question and answer activities between questioners and sources with the aim of obtaining information related to certain topics [30], [31]. For the interview stage, the subject is the site manager, the community around the site and the students who become the learning design simulator. Next is documentation, this stage is needed as evidence, in the form of physical evidence from the results of research that has been conducted by researchers [32]-[34]

In the final stage the researcher uses a quantitative approach. Where statistical numerical data is one of the references for making decisions [35]. This stage is carried out to measure the response of the simulators regarding a fun history learning design by exploring the air dampul situation. At this stage the simulators fill out a questionnaire regarding the assessment of the simulation results, both regarding the packaging and implementation. 


\section{Result and Discussion}

\subsection{History of water sites}

Water is a very important resource for human life [36]. The existence of water is usually often used for daily life, such as consumption for humans, plantation irrigation, and much more. Obtained water can be obtained from various sources, such as rainwater, surface water and ground water. The existence of springs, which are generally located in community settlements, triggers the use of source water flows, such as irrigation of community plantations, distribution of water sources to local residents' residences, and many more. This will not be separated from the name water management by the government in order to regulate the distribution of water, which in turn will flow the water sources to community areas that need clean water supply [37]-[39] . In this management, the pros and cons between the local community and the government will not go far. The use of springs in an integrated manner needs to be applied in maintaining and preserving the sustainability of spring sources. Strategies that are simple and easy to implement are essential to achieve sustainable management of integrated water resources based on environmental protection and empowerment of local communities. In the culture of the community, spring water cannot be separated from tradition and religion. The traditions in each spring are very diverse, ranging from site rituals in the form of bathing around the source, giving offerings, salvation, and much more [40]-[42].

Most of the water sources are found in highland areas (Arthana, 2004). Batu City, East Java, is one of the areas located in the highlands and surrounded by hills and mountains. Lots of researchers visited Batu City to study several springs that spread in the Batu City area [22], [43]. One of the water sources that is still preserved is the Dampul spring. Dampul Springs is the only water source located on the western slopes of Mount Arjuna and is one of the largest sources which is located at Jl. Besta Tulungrejo, Bumiaji District, Batu City, East Java. Access to the source is very easy because this route is often passed by tourists who want to take a vacation to Cangar hot springs and alternative routes to Mojokerto and Surabaya. The name Dampul is taken from one of the tree names, namely ficus lepicarpa. Topinimi from these plants if you look back at the lo or loa trees, they are still in one nation with pul (Dampul). The origin of the springs is very diverse, some come from gaps in rocks, gaps in the ground where the water will eventually emerge from underground to the surface in the form of springs. The water that appears at the Dampul spring comes from below and is in the form of mud or the residents of Besta village call it "endud". This Dampul spring spreads to the lower part of the Besta village area because the source is lower. If visitors are going to the spring, they will find a reservoir at the entrance. Besides, the reservoir can also be found near the source of the part below. Resource management itself is still managed by the residents of Besta village. Based on information from local residents, the volume of water that comes out of the source ranges from $10 \mathrm{~L} /$ second, and for a source depth of approximately $1 \frac{1}{2}$ to $2 \mathrm{~m}$. According to information, the water that comes out of the source is more waste because the water source area is in the valley. 


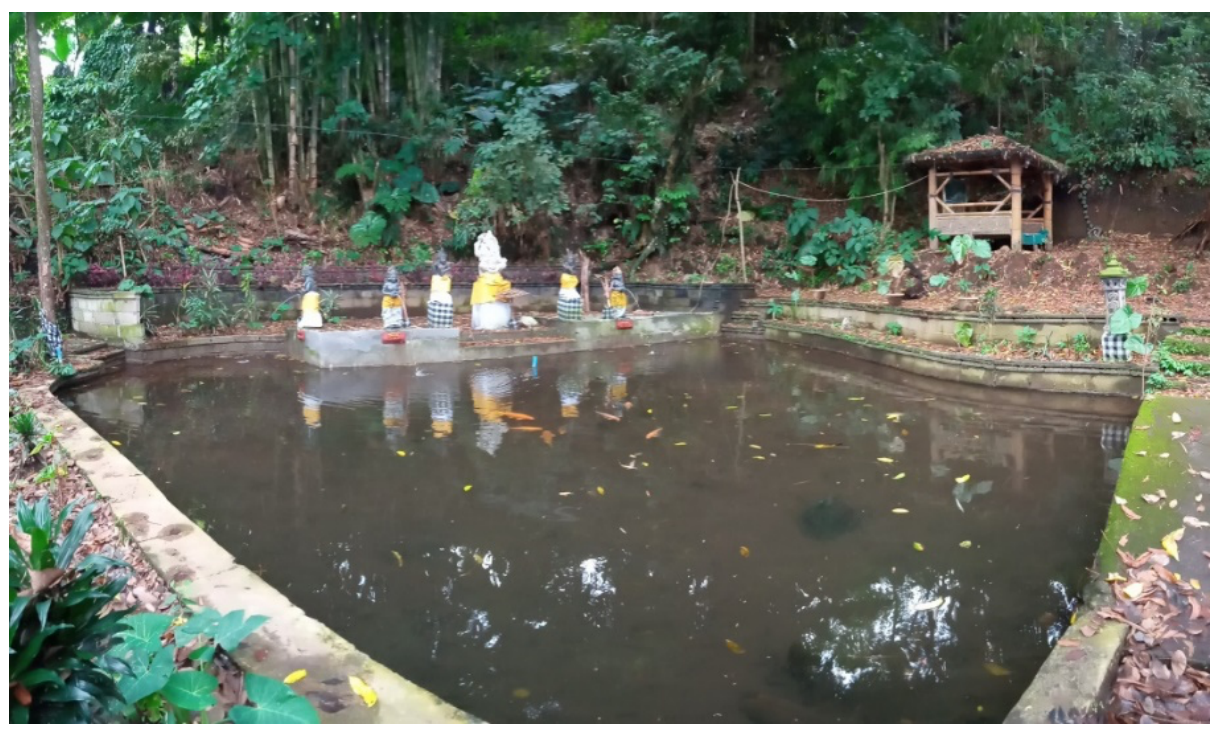

Fig. 1. The source of Matga Air in the Kampung in Besta Village, Batu City

In 2016 when one of the villagers served as one of the heads of the Rukun Warga (RW), Mr. Suwito (54) held mutual cooperation by cleaning the Dampul spring. In order to be more cared for and protected from these springs. The use of the source location is not only used by local residents but by Hindus in Tulungrejo Village. The utilization lasted a long time so that the maintenance of the source was also carried out by Hindus who also used the Dampul spring for purification purposes. Besides that, in addition to the water reservoir which is in front of the entrance, a prayer room will also be built, which is currently under construction. Utilization of Dampul springs is not only distributed for daily needs. The existence of a tradition inherent in the residents of Kampung Besta makes the Dampul spring more sustainable. Traditional traditions such as barikan and melasti are practiced by Hindus in Tulungrejo Village. The relationship between society and its surroundings is a form of harmonious unity that is always maintained in balance. Natural events such as earthquakes, famine, floods, epidemics are considered as signs for human life. With a good sign or a bad sign, it is hoped that the community will be prepared to face all possibilities based on these natural directions. To avoid this, the residents of Kampung Besta hold a tradition of barikan ceremonies. The ceremony is intended to reject reinforcements or calamities. Barikan or barikan salvation which means the word Bar (Javanese: finished) as a sense of gratitude and free from calamity.

Apart from the residents of Kampung Besta, Hindus living in Tulungrejo Village also protect the Dampul spring by utilizing the Dampul spring as purification (melasti) for Hindus because the Dampul spring can be said to be the grade of Dampul spring water that can be used for rituals. site. In Hinduism itself, to perform site rituals, there are water grade levels, namely Taya, Ware, and Tirta. In this grade of water, some are used for agriculture, some are used for consumption. Thus, it can be said that Hindus cannot just use water to perform site rituals because for purification (melasti) itself the 
grade of the source must be high, not all sources can be used. Although this spring is often used by Hindus, the Dampul spring is very open to the public.

Near the Dampul spring, there is a statue like a person praying, according to Hindu belief the statue gives a signal that the statue used to be someone who shrank (Ronggo Sekti). In Hinduism itself there is a concept of life level or commonly called Caturasrama (Brahmacari, Grehasta, Wanaprasta, \& Sanyasa), so people who have Wanaprasta gather at the Dampul spring. Thus, there are several groups of rishis or pandas. At the point where the spring appears there is a statue which is used as a sign. Among the statues there is a Ganesha statue and on the left and right there is also a statue under which is given a different name. The name is given based on its function, for example, purification If in Hinduism there are special prayers. Apart from Hindus, residents of Besta village also hold the 1 Suro salvation, the August 17 celebration which is usually held at the Dampul spring water yard. There are two site rituals known to local residents, namely site rituals related to religion and site rituals related to customs.

\subsection{Fun learning history design based on Android}

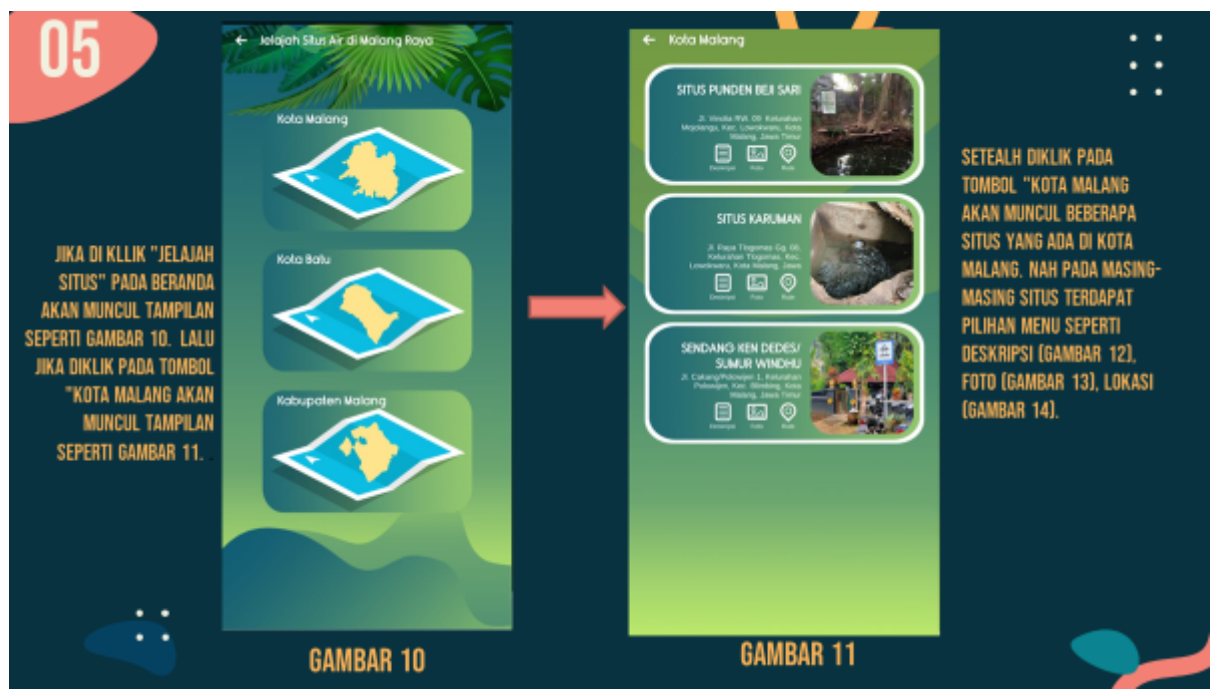

Fig. 2. Display Fun Learning in Android Applications

As one of the subjects taught to students, history is a subject that explains events that occurred in the past and is related to a series of events within a certain time frame. History subjects are still considered to be centered on educators so that students only passively hear the explanation of the material conveyed through the lecture method [44]. Character building in education is very necessary, as in history subjects which also build character in students to love the homeland, nurture and safeguard Indonesia's wealth. That way students are able to appreciate the services of the heroes who had previously built Indonesia. Likewise local history, students not only appreciate the 
heroes, soldiers who also took part in fighting but their ancestors who used to have chronicles part of Indonesia and one of them is the area we live in today. In addition, students are taught about how to respect the past so that it is not repeated in the future which is also learning, maintaining and preserving what has been built by the former (Abdullah \& Azis, 2019). History that contains local history, especially water sites packed on Android with applications that are easy to operate by students when carrying out learning activities. This application supports the fun learning method.

The method is a tool in the implementation of education, which is used in the delivery of the material. The material taught by educators must be conveyed properly and correctly. In addition, learning methods were made with the aim of making it easier for educators and students to be able to absorb the material presented [45]. The outdoor learning method is one method that is quite successful in improving student learning. This method connects students with learning resources according to the material needed. In addition to students, the teacher will also link the subject matter with the real world, so that students are able to develop their knowledge with everyday life[14], [46]. Students will be invited to directly explore the objects that are still there and find out directly from the source. That way students will not be passive when receiving the material presented. In history subjects, outdoor learning methods are highly recommended. Because there is so much historical material and students tend to be bored and bored when the teaching and learning process takes place. The existence of this method is recommended because students will be invited to explore historical places, sites, so that they are not fixated on textbooks that only see historical objects through pictures [24][26], [47]. There are several steps before implementing outdoor learning for students, namely:

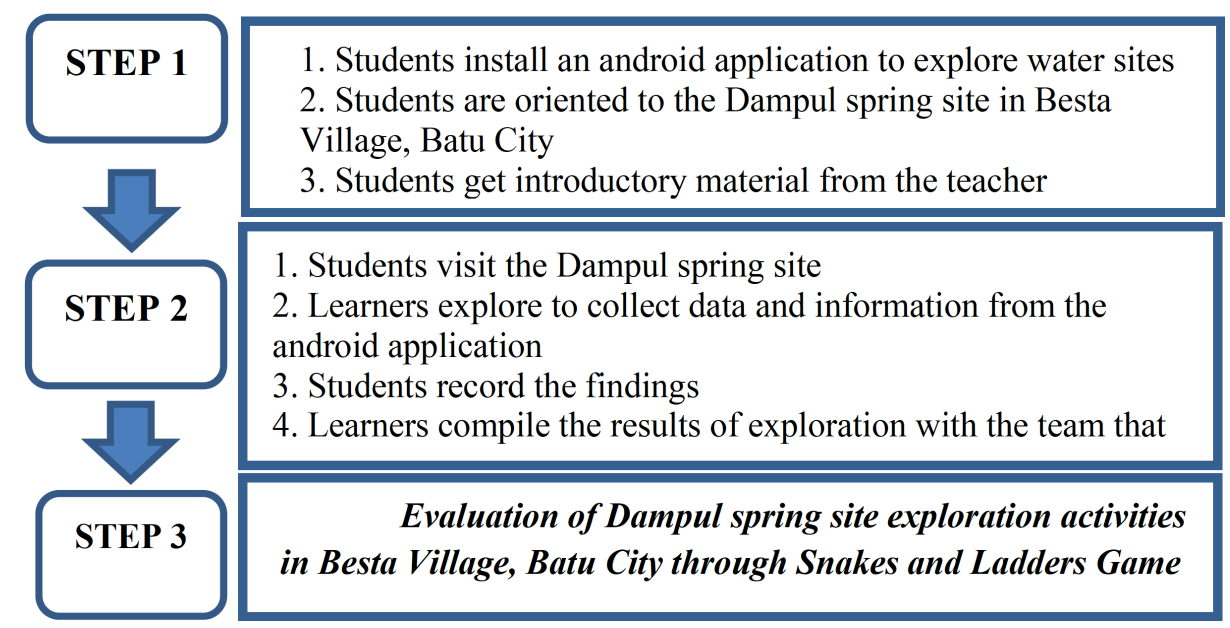

Fig. 3. Stages of fun learning history activities

Evaluation is needed when the implementation of teaching and learning activities has ended, with the aim that students remember the previously taught material [48]. Various kinds of evaluations were applied, such as appointing one of the students to 
make corrections in the form of what was obtained from the lesson that day, conducting tests such as oral tests and written tests. The evaluation model with a game model (games) is developed based on fun learning where students will be faced with several instructions and game rules [49]. That way students will not feel bored and bored when absorbing the material provided. Fun learning is intended for students to be more active and creative through some of the challenges given. Fun learning helps students when receiving material is more fun and can train students to be more active and dexterous in solving a challenge[49], [50].

The learning method based on fun learning will be applied to students in the form of snake and ladder game media. This game uses three tools, namely dice, pawns, and a snake and ladder board. The challenge with the results of the gap is in the form of questions on the snake and ladder banner. The steps for implementing an evaluation activity:

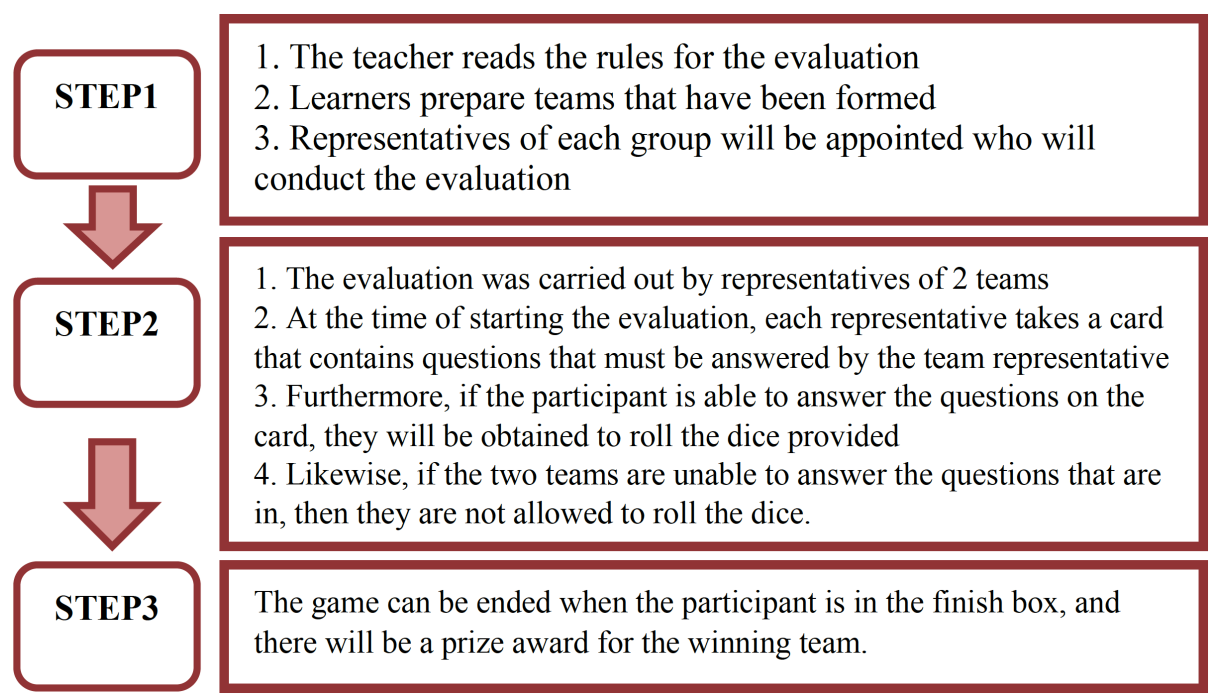

Fig. 4. Fun learning history evaluation stages

That way they will not feel bored, because they will learn directly through nature and end the evaluation using games. Usually, students will understand better through the experiences they have experienced. One of them is by browsing the site.

\subsection{Benefits and results of implementing fun learning history for Students}

In line with the character education that is built into history subjects, it has a good impact on the atmosphere in learning. Students will be carried away when learning takes place. The benefits of exploring the site are almost the same as the evaluation of fun learning as a historical lesson. Students will be trained in the social spirit of the community on how to promote courtesy when interacting with anyone. When visiting historical places, there must be regulations that apply to these places. For example, 
visitors are not allowed to litter, talk carelessly, do not touch and damage relics or other objects that are guarded, must say greetings when visiting historic places. Students will be taught to obey the rules that have been made. At the time of exploration there will definitely be where participants exchange opinions about the sites visited, students will be taught to respect each other who will argue, in addition to respecting the opinions of students, they will also respect other people of different ethnicities, races, and religions. Because we all live in Indonesia, which is multiculturalism with different backgrounds [51].

So even when the game of snake and ladder begins. They will be motivated to learn, remember, and be active during the evaluation process. After exploring the Dampul spring water site, they will be encouraged to recall the material they have obtained after exploring this historical site. The knowledge gained in the evaluation will be easier to remember because after they have explored and ended with an evaluation of playing snakes and ladders. So, with this situation, of course, will make it easier for students to do the final test so that the cognitive aspects of learning outcomes increase. In addition, the problems that exist in the field are often found to be bored with historical subjects. This makes teachers have to try to re-develop learning methods like what need to be applied in education, especially history subjects. One of them is a fun learning method based on this snake and ladder. Students will enjoy the learning process by playing [52], [53].

The benefits of developing the game of snakes and ladders are very numerous, not only pleasing students to be taught honesty, working together in teams, daring to express opinions on answering several challenges through questions that have been asked. The trend of history is indeed very boring if only studying in the classroom. Students also need to learn directly on objects, visit several historical sites, museums, play with learning. There is a possibility for students when transferring knowledge through games will be easier to remember. So that the students' brains are not always tense with the material presented. The existence of ice breaking is also very useful in learning so that students are not tense and bored [54], [55]. The game of snakes and ladders for history subjects is not just a game of snakes and ladders, but a game that is equipped with questions to increase students' interest in learning history, especially local history, because local history is not so raised in history subjects. In addition to the benefits of the educational learning method, through exploring the site students can be given knowledge about how to protect and conserve springs, how to manage these springs, and why the springs are divided into 3 in taking springs according to Hindus. So that the Dampul spring is maintained and maintained for its existence [26], [56].

For the achievement in simple implementation, the implementation of fun learning shows significant results. The trial subjects consisting of 15 samples gave positive responses to several assessment criteria. The results of the recapitulation of the questionnaire that the respondent must fill out are shown in the diagram below: 


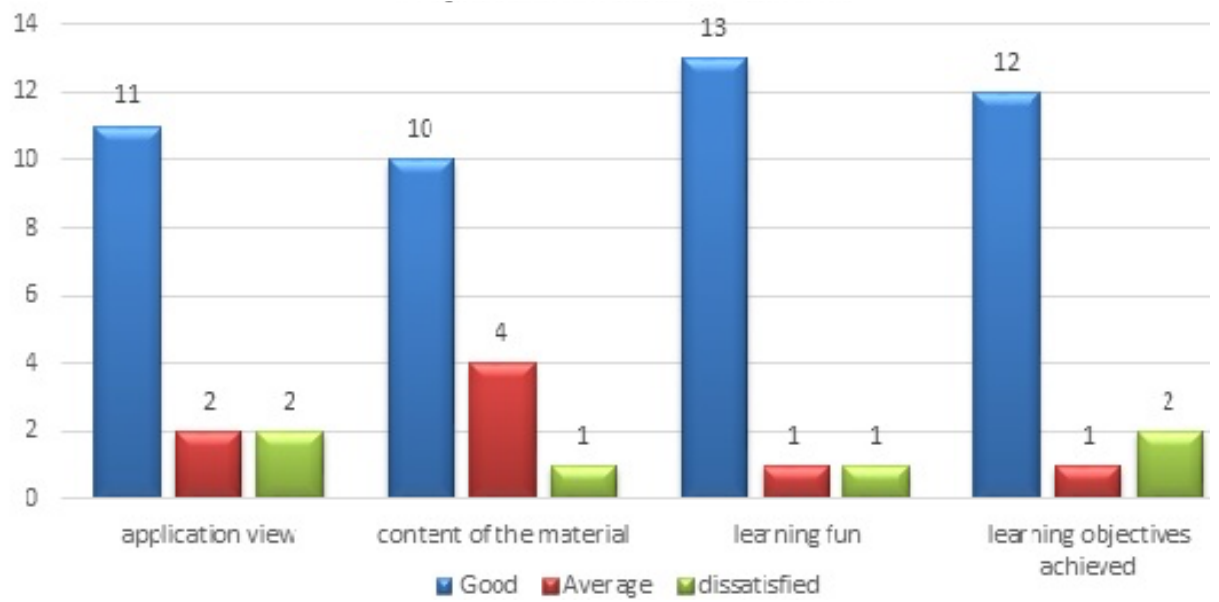

Fig. 5. Implementation result fun learning history

The diagram above shows the effectiveness of the fun learning learning design with the main subject of the history of the water situation in Batu City which is packaged through an android application. In the first criterion regarding the appearance of the application, the assessment score reached $73 \%$ said it was good and $13 \%$ chose average and dissatisfied. For the second criterion, $67 \%$ of the content of material said it was good, 27 said it was average and $6 \%$ said it was dissatisfied. The third criterion on the learning fun choice of good reached $87 \%$ and $13 \%$ stated that the average was dissatisfied. The fourth criterion regarding the learning objectivies archived shows that good choices reach $80 \%, 6 \%$ average and $14 \%$ dissatisfied. From the achievements in the fun learning history lesson design simulation, it has proven to be effective. Achievements in the success of packaging android applications in history learning are an alternative solution to learning history in this modern era.

\section{Conclusion}

History is one of the learning forms of national character, therefore it must be able to be taught and accepted by students both in terms of material and value. In the midst of the advancement of the era, teachers are required to be able to teach history well. Contribute three things, the first is the coverage of the material, the second is the way of teaching and the third is the packaging of learning. In the description above, it is clearly explained the answers to these challenges, first for material coverage, local history materials that are full of character values are selected, for teaching methods fun learning is chosen by combining games and outdoor activities in learning, and for packaging android packaging is chosen according to the pattern. children's study habits now.

Historical sites have an important importance in learning history in relation to the benefits of history as education. The Dampul spring site is one of the springs located in Batu City, which is located at Jln. Besta Tulungrejo, Bumiaji District, Batu City, East Java. The location of the Dampul spring is located in a residential area. In addition, 
Dampul sources are also close to the school. This provides an opportunity for students to learn about the local history in their area. Several learning methods were introduced in the world of education. One of them is a fun learning-based learning method. In addition, students will get knowledge about historical sites directly from nature through site exploration. With this, it is hoped that students will be able to understand the local history that exists in their respective areas, not only knowing but also taking part in protecting and preserving. The learning method that will be applied is site exploration and evaluation using the snake and ladder game media. By exploring the site, students will know objectively from historical objects or themes, forming character education while the snake and ladder game media aims to increase student activity, enthusiasm for learning, and have the courage to express opinions that will have an impact on increasing learning outcomes. students, and can make it easier for teachers to deliver learning material. The results of the implementation that involved students as limited trial subjects showed significant results for the success of the learning design in achieving the learning objectives.

\section{$5 \quad$ References}

[1] C. B. Davison and E. J. Lazaros, "Adopting Mobile Technology in the Higher Education Classroom," The Journal of Technology Studies, vol. 41, no. 1, Apr. 2015. https://doi.org/10.21061/jots.v41i1.a.4

[2] D. De Ferranti et al., Closing the gap in education and technology. The World Bank, 2003.

[3] P. Deitel, H. Deitel, and A. Deitel, Android how to Program. Prentice Hall Press, 2014.

[4] A. Ahmar and A. Rahman, "Development of teaching material using an Android," Global Journal of Engineering Education, vol. 19, no. 1, 2017.

[5] J. Andrus and J. Nieh, "Teaching operating systems using android," in Proceedings of the 43rd ACM technical symposium on Computer Science Education, 2012, pp. 613-618. https://doi.org/10.1145/2157136.2157312

[6] H. Fahri and K. Samsudin, "Mobile Learning Environment System (MLES): The Case of Android-based Learning Application on Undergraduates' Learning," IJACSA, vol. 3, no. 3, 2012. https://doi.org/10.14569/ijacsa.2012.030311

[7] O. A. Nanda and I. Wilujeng, "The Effectiveness of Android-assisted Optical Devices Learning to Improve Students' Conceptual Understanding," JurnalPenelitian dan Pembelajaran IPA, vol. 4, no. 2, pp. 105-115, 2018. https://doi.org/10.30870/jppi.v4i2.4038

[8] S. Sari, R. Anjani, I. Farida, and M. A. Ramdhani, "Using android-based educational game for learning colloid material," in Journal of Physics: Conference Series, 2017, vol. 895, p. 012012. https://doi.org/10.1088/1742-6596/895/1/012012

[9] I. G. Widja, Sejarah lokalsuatuperspektifdalampengajaransejarah. PenerbitAngkasa, 1991.

[10] E. N. Arifin, A. Ananta, D. R. Wilujeng Wahyu Utami, N. Budi Handayani, and A. Pramono, "Quantifying Indonesia's ethnic diversity: Statistics at national, provincial, and district levels," Asian Population Studies, vol. 11, no. 3, pp. 233-256, 2015. https://doi.org/10. 1080/17441730.2015.1090692

[11] T. Modood, "Multiculturalism," The Blackwell Encyclopedia of Sociology, pp. 1-4, 2007.

[12] K. Clarke, Making time for the past: local history and the polis. Oxford University Press, 2008.

[13] W. G. Hoskins and D. Hey, Local history in England. Routledge, 2014. 
[14] W. W. Cobern, "Contextual constructivism: The impact of culture on the learning and teaching of science," in the practice of constructivism in science education, Routledge, 2012, pp. 67-86. https://doi.org/10.4324/9780203053409-9

[15] M. Aston, Interpreting the landscape: landscape archaeology and local history. Rout-ledge, 2002.

[16] K. D. Squire, J. G. MaKinster, M. Barnett, A. L. Luehmann, and S. L. Barab, "De-signed curriculum and local culture: Acknowledging the primacy of classroom culture," Science education, vol. 87, no. 4, pp. 468-489, 2003. https://doi.org/10.1002/sce.10084

[17] K. S. Zimmerer, "Cultural ecology: at the interface with political ecology-the new geographies of environmental conservation and globalization," Progress in Human Geo-graphy, vol. 30, no. 1, pp. 63-78, 2006. https://doi.org/10.1191/0309132506ph591pr

[18] I. S. Angin, "KearifanLokal Masyarakat DalamMenjagaKelestarianHutan Dan Men-gelola Mata Air Di DesaWatowara, KecamatanTitehenaKabupaten Flores Timur Nusa Tenggara Timur," geoedusains: Jurnal Pendidikan Geografi, vol. 1, no. 1, pp. 51-61, 2020. https://doi.org/10.30872/geoedusains.v1i1.195

[19] M. R. Lubis, "Kearifanlokaldalampengelolaanmata air di desasungailangka, kecamatangedongtataan, kabupatenpesawaran, provinsilampung," 2018.

[20] R. Sufia, S. Sumarmi, and A. Amirudin, "Kearifanlokaldalammelestarikanlingkun-ganhidup (studikasusmasyarakatadatDesaKemirenKecamatanGlagahKabupatenBa-nyuwangi)," Jurnal Pendidikan: Teori, Penelitian, dan Pengembangan, vol. 1, no. 4, pp. 726-731, 2016.

[21] Jatz, "TokoRamedari Masa ke Masa | Kisah Kota Batu," 2017. https://batukota.wordpress.com/2017/05/04/toko-rame-dari-masa-ke-masa/ (accessed May 25, 2019). https://doi.org/10.14203/jmb.v20i3.768

[22] R. Amalia, "OptimasiAlokasi Air BerbasisKetersediaan dan Kebutuhan Air di Kota Batu.," PhD Thesis, Universitas Brawijaya, 2015.

[23] P. Rejekiningrum, "PeluangPemanfaatan Air Tanah untukKeberlanjutanSumberDaya Air," JurnalSumberdayaLahan Vol, vol. 3, no. 2, 2009.

[24] S. I. Hana and W. D. Sulistyo, "The Utilization of Colonial Government Buildings in Malang as the Learning Sources," Feb. 2020, pp. 278-282, doi: 10.2991/assehr.k.200214.049.

[25] W. D. Sulistyo, M. N. L. Khakim, B. Kurniawan, and A. D. S, "Learning experience from learning sources: exploiting geographic and historical potential of guerrilla sites in WonokartoPacitan as a source of historical learning," IOP Conf. Ser.: Earth Environ. Sci., vol. 485, p. 012109, Jun. 2020. https://doi.org/10.1088/1755-1315/485/1/012109

[26] W. D. Sulistyo, M. N. L. Khakim, B. Kurniawan, and R. Pratama, "Historical Learning with Outdoor Learning: Utilization of the General Sudirman Monument Historical Site in NawanganPacitan as a Learning Resource," Feb. 2020, pp. 172-177. https://doi.org/10.2991/assehr.k.200214.029

[27] W. D. Sulistyo, M. N. L. K, and B. Kurniawan, "The Development of 'JEGER' Ap-plication Using Android Platform as History Learning Media and Model," International Journal of Emerging Technologies in Learning (iJET), vol. 15, no. 07, Art. no. 07, Apr. 2020. https://doi.org/10.3991/ijet.v15i07.11649

[28] W. D. Sulistyo and U. N. Idris, "The Development of E-PAS Based on Massive Open Online Courses (MOOC) on Local History Materials., International Journal of Emerging Technologies in Learning, vol. 14, no. 9, 2019. https://doi.org/10.3991/ijet.v14i09.10143

[29] J. W. Creswell and J. D. Creswell, Research design: Qualitative, quantitative, and mixed methods approach. Sage publications, 2017. https://doi.org/10.7748/nr.12.1.82.s2

[30] B. DiCicco-Bloom and B. F. Crabtree, "The qualitative research interview," Medical education, vol. 40, no. 4, pp. 314-321, 2006. https://doi.org/10.1111/j.1365-2929.2006.02418.x 
[31] D. W. Turner III, "Qualitative interview design: A practical guide for novice investi-gators," The qualitative report, vol. 15, no. 3, p. 754, 2010.

[32] S. Beltramo, E. Donadio, and A. Spanò, "Stratigraphic Analyses, Historical Evidences, and 3D Documentation Tools: Deepening Built Heritage-New Researches for Historical Building Sites in Staffarda," in Analysis, Conservation, and Restoration of Tangible and Intangible Cultural Heritage, IGI Global, 2019, pp. 273-301. https://doi.org/10.4018/978-1-52256936-7.ch012

[33] A. M. Mäkelä and N. Nimkulrat, "Reflection and documentation in practice-led design research," Nordes, no. 4, 2011.

[34] F. Remondino and A. Rizzi, "Reality-based 3D documentation of natural and cultural heritage sites - techniques, problems, and examples," Applied Geomatics, vol. 2, no. 3, pp. 85100, 2010. https://doi.org/10.1007/s12518-010-0025-x

[35] H. R. Bernard and H. R. Bernard, Social research methods: Qualitative and quantitative approaches. Sage, 2013.

[36] M. F. Chaplin, "Water: its importance to life," Biochemistry and Molecular Biology Education, vol. 29, no. 2, pp. 54-59, 2001. https://doi.org/10.1016/s1470-8175(01)00017-0

[37] B. D. Richter, R. Mathews, D. L. Harrison, and R. Wigington, "Ecologically sustain-able water management: managing river flows for ecological integrity," Ecological appli-cations, vol. 13, no. 1, pp. 206-224, 2003. https://doi.org/10.1890/1051-0761(2003)013[0206:eswm $\underline{\mathrm{mr}}]$ 2.0.co;2

[38] V. Vebrianti and R. Musyawarah, "DeskripsiTentangPemanfaatanSumber Mata Air JompiKelurahanLaendeKecamatanKatobuKabupatenMuna," LaGeografia, vol. 18, no. 1, pp. 55-62, 2019.

[39] A. B. Wurianto, “Aspekbudaya pada upayakonservasi air dalam situs kepurbakalaan dan mitologimasyarakat Malang,” Jurnal Humanity, vol. 4, no. 2, 2012.

[40] M. K. Sallata, "Konservasi dan pengelolaansumberdaya air berdasarkankeberadaan-nyasebagaisumberdayaalam," Buletin Eboni, vol. 12, no. 1, pp. 75-86, 2015.

[41] N. Sharma and P. Kanwar, "Indigenous water conservation systems-A rich tradition of rural Himachal Pradesh," 2009.

[42] S. Sudarmadji, D. Darmanto, M. Widyastuti, and S. Lestari, "Pengelolaanmata air un-tukpenyediaan air rumahtanggaberkelanjutan di lereng Selatan Gunungapi Merapi (Springs Management for Sustainability Domestic Water Supply in the South West of Merapi Volcano Slope)," JurnalManusia dan Lingkungan, vol. 23, no. 1, pp. 102-110, 2016. https://doi.org/10.22146/jml.18779

[43] D. Taryana, "PengaruhFormasiGeologiterhadapPotensi Mata Air di Kota Batu," Jurnal Pendidikan Geografi, vol. 20, no. 2, 2016. https://doi.org/10.17977/um017v20i22015p009

[44] S. H. Hasan, "Problematika Pendidikan Sejarah," Bandung: FPIPS UPI, 2003.

[45] A. Drejer, "Innovation and learning," International Journal of Innovation and Learning, vol. 1, no. 1, pp. 9-23, 2003.

[46] E. B. Johnson, Contextual teaching and learning: What it is and why it's here to stay. Corwin Press, 2002.

[47] W. D. Sulistyo, "Study on Historical Sites: Pemanfaatan Situs Sejarah Masa Kolonial di Kota Batu sebagaisumberpembelajaranberbasis outdoor Learning," Indonesian Journal of Social Science Education (IJSSE), vol. 1, no. 2, pp. 124-135, 2019.

[48] S. Odeh and O. Qaraeen, "Evaluation methods and techniques for e-learning software for school students in primary stages," International Journal of Emerging Technologies in Learning (iJET), vol. 2, no. 3, 2007. 
[49] A. Amory and R. Seagram, "Educational game models: conceptualization and evalua-tion: the practice of higher education," South African Journal of Higher Education, vol. 17, no. 2, pp. 206-217, 2003. https://doi.org/10.4314/sajhe.v17i2.25314

[50] M. Kalogiannakis and S. Papadakis, "An evaluation of Greek educational Android apps for preschoolers," in proceedings of the 12th Conference of the European Science Education Research Association (ESERA), Research, Practice and Collaboration in Science Education, Dublin City University and the University of Limerick, Dublin, Ireland, 2017, pp. 21-25.

[51] W. Wasino, "Indonesia: from Pluralism to Multiculturalism," Paramita: Historical Studies Journal, vol. 23, no. 2, 2013.

[52] S. Lisdayeni, D. Darsono, and R. M. Sinaga, "PenerapanMetode Outdoor Study da-lamMeningkatkan Minat Belajar dan Keterampilan Sosial Siswa," Jurnal Studi Sosial, vol. 3, no. 3, 2015.

[53] K. Rapeepisarn, K. W. Wong, C. C. Fung, and A. Depickere, "Similarities and differ-ences between" learn through play" and" edutainment"," 2006.

[54] R. Hutasoit and B. Tambunan, "The Effect of Ice Breaking Technique in Teaching Speaking at the Tenth Grade Students of SMK Dharma Bhakti Siborongborong in Academic Year 2018/2019," International Journal of English Literature and Social Sciences, vol. 3, no. 5, 2018. https://doi.org/10.22161/ijels.3.5.2

[55] M. D. Kurniasih and D. H. Lenaldi, "The effect of ice-breaking using stand-up comedy on students' mathematical belief system," in Journal of Physics Conference Series, 2018, vol. 948, no. 1, p. 012011. https://doi.org/10.1088/1742-6596/948/1/012011

[56] K. Burriss and L. Burriss, "Outdoor play and learning: Policy and practice.," Interna-tional Journal of Education Policy and Leadership, vol. 6, no. 8, pp. 1-12, 2011. https://doi.org/10.22230/ijepl.2011v6n8a306

\section{Authors}

Wahyu Djoko Sulistyo, Moch. Nurfahrul Lukmanul Khakim, Najib Jauhari, Rena Dwita Anggraeni are from Universitas Negeri Malang. Wahyu.djoko.fis@, um.ac.id

Article submitted 2021-01-06. Resubmitted 2021-02-25. Final acceptance 2021-02-26. Final version published as submitted by the authors. 